\title{
Radiologic features of symptomatic cholelithiasis: a current perspective
}

\section{Semptomatik kolelitiyazisin radyolojik özellikleri: güncel bir bakış}

\author{
(1)Adnan Özdemir'1 ${ }^{1}$ Mehmet Hamdi Şahan ${ }^{2}$ \\ ${ }^{1}$ Kırıkkale University, School of Medicine, Department of Radiology, Kırıkkale, Turkey \\ ${ }^{2}$ Gaziantep University, School of Medicine, Department of Radiology, Gaziantep, Turkey
}

Cite this article as/Bu makaleye atıf için: Özdemir A, Şahan $\mathrm{MH}$. Radiologic features of symptomatic cholelithiasis: a current perspective. J Health Sci Med 2020; 3(4): 466-472.

\begin{abstract}
Aim: The aim of this study was to investigate the radiological features of symptomatic cholelithiasis with use radiography, ultrasonography (USG), and computed tomography (CT).

Material and Method: From January 2014 and September 2019, 543 patients with cholelithiasis were identified. Of these, 174 who also underwent radiography and CT were included in the study. During the 3-year follow-up of the 174 patients, 80 patients had symptomatic cholelithiasis, identified according to USG and/or CT examinations, as well as clinical findings. Findings suggesting cholecystitis, cholangitis, pancreatitis, and choledocholithiasis were accepted as symptomatic. Radio-opaque stones were identified on radiography and stones were visible on CT. The stones were divided into groups according to their calcification types. The Hounsfield unit (HU) values of the stones were measured and the number and size of the stones were determined by CT and USG.

Findings and Results: Symptomatic findings included radio-opaque stones, multiple stones, stones with HU values above $100 \mathrm{HU}$, and cholelithiasis of the uniform calcification type $(\mathrm{p}<0.05)$. However, the relationship between symptomatic cholelithiasis and stone size was not significant $(\mathrm{p}>0.05)$.

Conclusion: The radiological features of symptomatic cholelithiasis are important in terms of follow-up, treatment plan and prevention of complications.
\end{abstract}

Keywords: Cholelithiasis, radio-opaque, symptomatic, complication, radiography

\section{ÖZ}

Amaç: Bu çalışmanın amacı, radyografi, ultrasonografi (USG) ve bilgisayarlı tomografi (BT) kullanarak semptomatik kolelitiazisin radyolojik özelliklerini araştırmaktır.

Gereç ve Yöntem: Ocak 2014 ve Eylül 2019'dan itibaren 543 kolelitiyazisli hasta belirlendi. Bunlardan hem radyografi hem de BT’si çekilen 174'ü çalışmaya dahil edildi. 174 hastanın 3 yıllık takibinde 80 hastada USG ve/veya BT incelemelerine ve klinik bulgulara göre tespit edilen semptomatik kolelitiyazis vardı. Kolesistit, kolanjit, pankreatit ve koledokolitiazisi düşündüren bulgular semptomatik olarak kabul edildi. Radyografide radyoopak taşlar belirlendi ve BT'de taşlar görüldü. Taşlar kalsifikasyon türlerine göre gruplara ayrıldı. Taşların Hounsfield birimi (HU) değerleri ölçülerek taş sayısı ve boyutu BT ve USG ile belirlendi.

Bulgular ve Sonuç: Radyoopak taşlar, çoklu taşlar, HU değerleri 100 HU'nun üzerinde olan taşlar ve tek tip kalsifikasyon tipinde safra taşlarında semptomatik bulgular vardı $(\mathrm{p}<0,05)$; ancak semptomatik kolelitiazis ile taş boyutu arasındaki ilişki anlamlı değildi ( $\mathrm{p}>0,05)$. Semptomatik kolelitiyazisin radyolojik özellikleri takip, tedavi planı ve komplikasyonların önlenmesi açısından önemlidir.

Anahtar kelimeler: Kolelitiyazis, radyo-opak, semptomatik, komplikasyon, radyografi 


\section{INTRODUCTION}

Cholelithiasis is the most common disease of the digestive tract after peptic ulcer, and cholelithiasis diseases are encountered in $10 \%$ of the general population (1-3). Approximately $70-80 \%$ of patients with cholelithiasis have asymptomatic cholelithiasis that remains silent for life (2-5). Symptoms of asymptomatic cholelithiasis initially occur in $10 \%$ of patients in the first 5 years after diagnosis and in $25.8 \%$ in 10 years (5). The most common complaint in symptomatic cholelithiasis is recurrent abdominal pain, sometimes accompanied by nausea and vomiting. Abdominal swelling and belching may also occur. Mostly, complications such as cholecystitis and pancreatitis develop. Other complications, such as empyema and gallbladder perforation, occur in only $0.1 \%$ of cases $(3,5)$. The gold standard for noninvasive diagnosis of cholelithiasis is ultrasonography (USG), with a specificity and sensitivity above $95 \%(3,4)$. In some cases, radiographic examination or computed tomography $(\mathrm{CT})$ is used, as well as diagnostic procedures such as magnetic resonance cholangiopancreatography, endoscopic retrograde cholangiopancreatography (ERCP) and cholangioscopy for the biliary and common bile duct stones $(3,6,7)$.

Gallstones are composed mainly of cholesterol, bilirubin, and calcium salts, with smaller amounts of protein and other materials (8-10). Three types of gallstones are recognized: (I) Pure cholesterol stones, which contain at least $90 \%$ cholesterol, (II) pigment stones, which are either brown or black and contain at least $90 \%$ bilirubin, and (III) mixed composition stones, which contain varying proportions of cholesterol, bilirubin, and other substances (such as calcium carbonate, calcium phosphate, and calcium palmitate) (8). Brown pigment stones are mainly composed of calcium bilirubinate, whereas black pigment stones contain bilirubin, calcium, and/or tribasic phosphate (8-13). The composition of the stones also affects the treatment. Pigment stones are easily removed by endoscopic lithotripsy, whereas cholesterol stones, which are harder in texture, are more difficult to remove by endoscopic treatment (7). Oral dissolution therapy with bile acids is used in selected patients, but the primary treatment for symptomatic cholelithiasis disease is surgery (4-6).

The components of cholelithiasis determine the radiological features, which may be useful in treatment planning. To the best of our knowledge, no recent studies in the literature have explored the radiographic features of cholelithiasis (14-17). The aim of the present study was to use radiography, USG, and CT to investigate the radiological features of symptomatic cholelithiasis.

\section{MATERIAL AND METHOD}

This retrospective study was conducted in Kirıkkale University Faculty of Medicine according to the principles of the Declaration of Helsinki. Abdominal USG, radiography and CT scans were examined from the database of the Kirıkkale University Faculty of Medicine Radiology Department. Approval for the study was granted by the Ethics Committee of Kirıkkale University Faculty of Medicine (Date: 24.10.2018, Number: 18/8).

\section{Study Design}

A total of 543 patients with cholelithiasis underwent abdominal ultrasonography between January 2014 and September 2019, and 174 patients with both radiography and CT scans were included in the study. The demographic, radiological and clinical information of the patients was obtained by scanning the files in the hospital registry system. The 3-year follow-up of the 174 patients revealed 80 patients with symptomatic cholelithiasis, identified according to USG and/or CT examinations, together with clinical findings.

Patients under 18 years of age, with primary malignancies of the liver and biliary tract, with metastatic lesions, or with gallbladder malignancy were excluded from the study.

\section{Equipment and Evaluations}

Ultrasonographic examinations were performed with a convex probe of 3-5 MHz (Toshiba Aplio 500; Canon Medical Systems, USGA). Radiography and digital X-ray (XGEO GC80, Samsung, Korea) images were obtained with the patient in the supine position. All patients were scanned using a 64-Multislice Computed Tomography (MSCT) instrument (Brilliance 64; Philips Medical System, Best, the Netherlands). The CT scans were acquired in a craniocaudal direction with the following parameters: collimation, $16 \mathrm{~mm} \times 1.5 \mathrm{~mm}$; section thickness, $3.0 \mathrm{~mm}$; transverse and coronal reconstruction interval, $3 \mathrm{~mm}$; pitch, 1.2; tube current, $120 \mathrm{kVp}$; and 200-300 mAs. Enhanced and nonenhanced CT scans were examined in all patients. The enhanced CT examinations were conducted using $350 \mathrm{mg} / \mathrm{mL}$ iohexol at a total dose of $90 \mathrm{~mL}$ and an injection rate of 3 to $4 \mathrm{~mL} / \mathrm{s}$.

The radiographic examinations of the patients with the ultrasound stone were evaluated for the presence or absence of radio-opaque stones. The CT images were also examined for the presence of stones visible on the CT images. The presence or absence of calcification evident on CT images was used to divide the patients into two groups. According to Federle et al. (2) calcification types can be classified into four groups, (I) Uniform type, with homogeneous calcification, (II) laminar type, 
with round, layered calcification, (III) annular type, with central, hypodense, round calcification, and (IV) central nidus, with surrounding hypodense, central calcification (Figure 1). The Hounsfield unit (HU) values of the stones were also measured. The region of interest (ROI) of the $\mathrm{HU}$ includes the entire stone (radiolucent and radiopaque components). The mean value of multiple stones was taken.

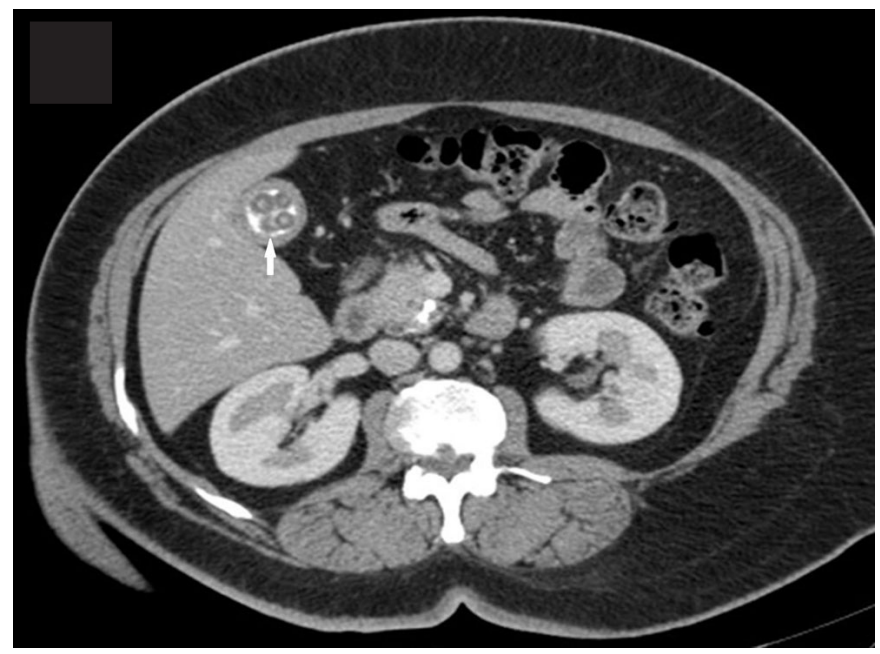

Figure 1. Laminar types of calcification of cholelithiasis as seen by abdominal CT (white arrows).

The sizes of the stones were determined based on both CT and USG findings; however, stones that were not visible on CT were measured based only on the USG findings. The maximum diameter of a stone was measured from the CT images on which the stone was most prominent. The stone sizes and the maximum diameter of the largest stone were measured in the USG examination, whereas the number of stones was recorded as single, a few pieces (2-4 pieces), and multiple stones ( $\geq 5$ pieces) using both USG and CT. The stone sizes were divided into the following 5 groups: $5 \mathrm{~mm}, 5-15 \mathrm{~mm}, 15-20 \mathrm{~mm}, 20-25$ $\mathrm{mm}$, and $25 \mathrm{~mm}$. The numbers and sizes of the stones were classified according to the cholelithiasis guideline proposed by Tazuma et al. (6) in 2016.

Patients with symptomatic cholelithiasis were identified according to their USG and/or CT examinations, together with their clinical findings. In general, the clinical findings in all patients were severe abdominal pain (upper abdomen or right upper quadrant pain, epigastric), nausea, vomiting, and/or jaundice and were supported by the laboratory findings (biluribin, alanine aminotransferase (ALT), aspartate aminotransferase (AST), alkaline phosphatase (ALP), gamma glutamyl transpeptidase (GT), amylase, lipase etc.). Those with findings of cholecystitis, cholangitis, pancreatitis and choledocholithiasis were considered symptomatic $(4,6,18)$ (Table 1).

\begin{tabular}{|c|c|c|}
\hline Diagnosis & $\mathrm{N}(\%)$ & Accompanying, N (\%) \\
\hline Acute cholecystitis & $\begin{array}{c}64 \\
(80 \%)\end{array}$ & $\begin{array}{c}6 / 2 \text { (choledocholithiasis/ } \\
\text { pancreatitis) }(10 \%)\end{array}$ \\
\hline Chronic cholecystitis & $\begin{array}{c}11 \\
(13.75 \%)\end{array}$ & \\
\hline $\begin{array}{l}\text { Cholangitis/ } \\
\text { choledocholithiasis }\end{array}$ & $4(5 \%)$ & \\
\hline Pancreatitis & $\begin{array}{c}1(1.25 \\
\%)\end{array}$ & \\
\hline Totally & $\begin{array}{c}80 \\
(100 \%)\end{array}$ & \\
\hline
\end{tabular}

In the USG images, a gallbladder wall thickness greater than $3 \mathrm{~mm}$ and the presence of pericolecystic fluid and gallbladder distension (transverse diameter $>40 \mathrm{~mm}$ ) were considered diagnostic criteria for acute cholecystitis $(3,4,6,18)$. In the CT images, these criteria were gallbladder wall thickening $(>3-5 \mathrm{~mm})$, excessive contrast enhancement in the wall or mucosa, inflammatory changes in the adjacent soft tissues and pericolecystic fluid, and abnormal gallbladder distention (Figure 2) $(4,6,18,19)$. The diagnosis of chronic cholecystitis was made based on a gallbladder wall thickness greater than $3 \mathrm{~mm}$ observed in the USG and CT images, without gallbladder distension (transverse diameter $<40 \mathrm{~mm}$ ) (Figure 3) (19). These criteria were standardized according to a previously published study guideline $(4,6,18,19)$.

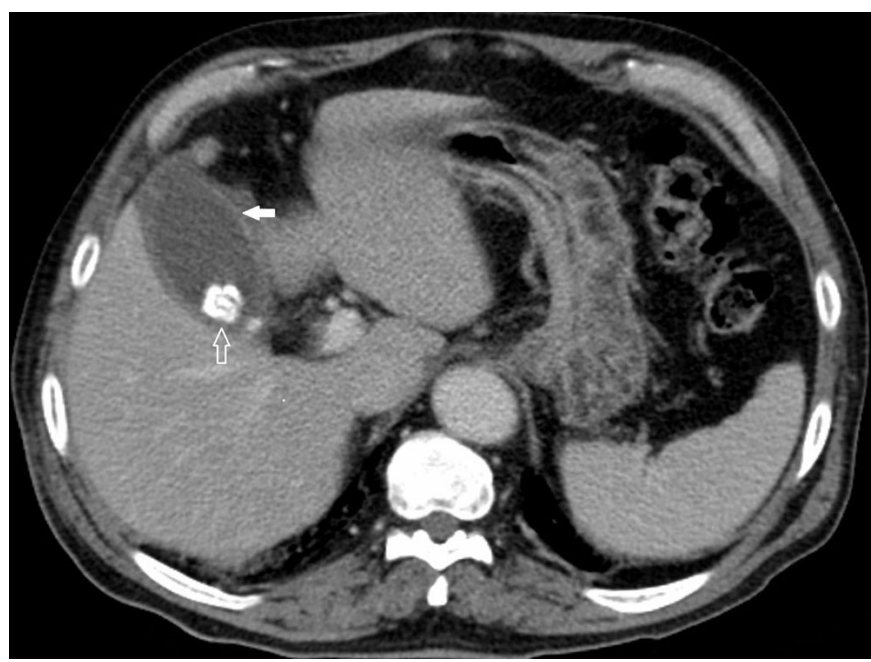

Figure 2. A 78-year-old male patient. Acute cholecystitis was evident on abdominal CT, as indicated by the increased wall thickness of the gallbladder, mucosal enhancement (white arrow), and a calcified stone (open arrow)

Diagnosis of cholangitis/choledocholithiasis: Bile duct wall thickening, dilatation and/or sludge, CT thickening of the bile duct walls, inflammatory changes around the bile duct, and the presence of stones in the biliary tract were evaluated in the USG images $(4,6,18,19)$. Pancreatitis was diagnosed with clinical and laboratory findings along with radiological findings. All pancreatitis patients had severe epigastric pain accompanied by nausea and vomiting. Edematous, hypoechoic, pancreatic 
enlargement and heterogeneity in the pancreas were evaluated in the USG images. The presence of contrastrepellent areas suggestive of necrosis or enhancement of the parenchyma and lines of inflammation due to inflammation in the surrounding fat tissue planes (Figure 4 ), or with or without cystic formation, were evaluated in the CT images $(3,6,14,18,19)$.

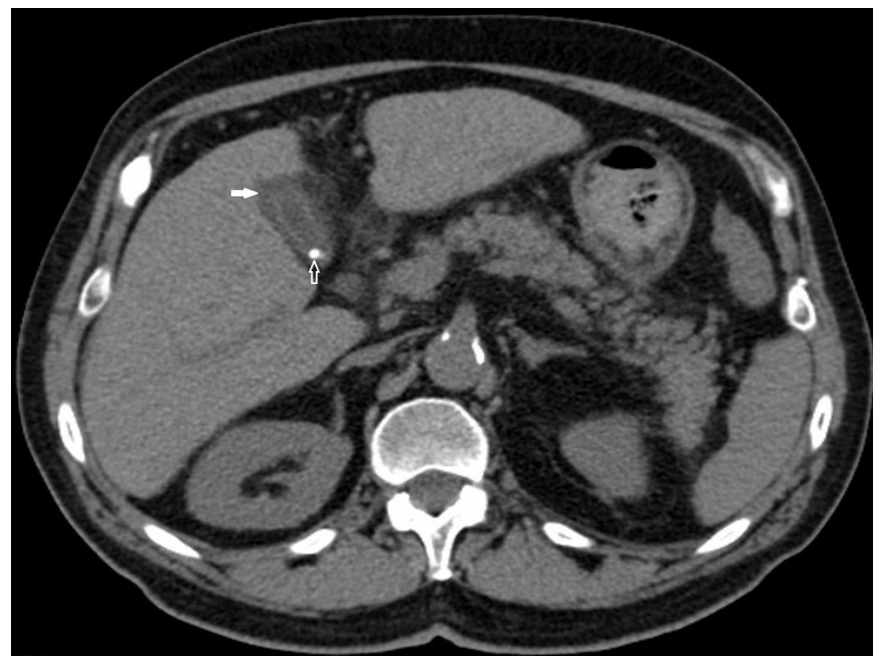

Figure 3. A 71-year-old female patient. Chronic cholecystitis was evident on abdominal CT, as indicated by the increased wall thickness of the gallbladder, without distention (white arrow), and a millimeter-scale calcified stone (open arrow)

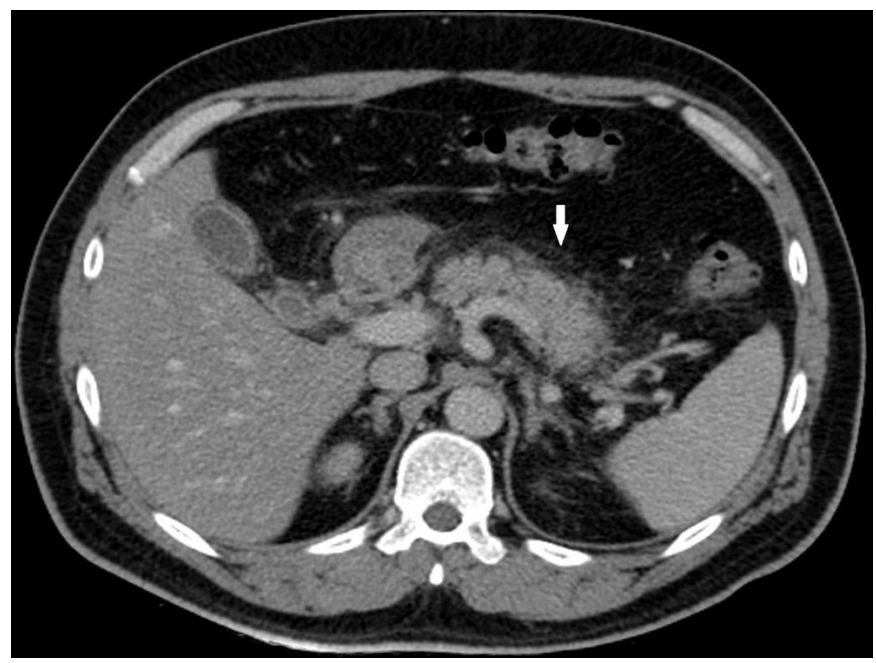

Figure 4. A 46-year-old male patient, Pancreatitis on abdominal $\mathrm{CT}$, inflammation lines due to inflammation in the fat tissue planes surrounding the pancreas (white arrow)

The follow-up USG and CT images of the patients after the first cholelithiasis diagnosis were also examined, and symptomatic cholelithiasis was detected during followup. A routine cholelithiasis follow-up protocol, as well as radiological examinations, was performed according to the clinical findings (4-6). The relationship between the different radiological features of cholelithiasis and symptomatic patients was evaluated. All USG, radiographic, and $\mathrm{CT}$ scanning images were examined as blinded to clinical data by a radiologist (AÖ) with 10 years of experience in general radiology.

\section{Statistical Analysis}

We used the SPSS software package program (SPSS, Chicago, Illinois, USGA), version 20.0, for statistical analyses. Data were expressed as the arithmetic mean \pm standard deviation (SD) and range. The independent t-test was utilized to compare patient ages with symptomatic and asymptomatic cholelithiasis. The radiological features of cholelithiasis were compared using the $\chi 2$ test to determine the relationship between symptomatic and asymptomatic cholelithiasis. Gender differences among the groups were also compared with the $\chi 2$ test. A P value of less than 0.05 was considered statistically significant.

\section{RESULTS}

Of the 174 patients with cholelithiasis, 101 were female (mean age 63.43 \pm 17.23 ) and 73 were male (mean age 63.19 \pm 14.29$)$. The demographic characteristics of the patients with symptomatic and asymptomatic cholelithiasis are shown in Table 2.

\begin{tabular}{|c|c|c|c|}
\hline & $\begin{array}{l}\text { Asymptomatic } \\
(\mathrm{N}=94)\end{array}$ & $\begin{array}{c}\text { Symptomatic } \\
(\mathrm{N}=\mathbf{8 0})\end{array}$ & $\begin{array}{c}P \\
\text { value }\end{array}$ \\
\hline Age, years & $\begin{array}{l}61.78 \pm 15.7 \\
(23-91)\end{array}$ & $\begin{array}{c}65.15 \pm 16.1 \\
(25-100)\end{array}$ & $0.167^{a}$ \\
\hline $\begin{array}{l}\text { Gender } \\
\text { male/female }\end{array}$ & $40 / 54$ & $33 / 47$ & $>0.05^{\mathrm{b}}$ \\
\hline \multicolumn{4}{|c|}{$\begin{array}{l}\text { Values are expressed as mean } \pm \mathrm{SD} \text { (range) where applicable } \\
\text { alndependent } t \text { test } \\
{ }^{b} x^{2} \text { analysis }\end{array}$} \\
\hline
\end{tabular}

The evaluation of symptoms related to cholelithiasis revealed cholecystitis in 75 patients (acute cholecystitis in 64 patients and chronic cholecystitis in 11 patients), choledocholithiasis in 3 patients, pancreatitis in 1 patient, and cholangitis in 1 patient. Six of the patients with acute cholecystitis also showed concurrent cholangitis/ choledocholithiasis. Two of the patients with findings of acute cholecystitis also had concomitant findings of pancreatitis. The distribution of diagnosis associated with the cholelithiasis is shown in Table 1.

The radiological features of radio-opacity, multiple stones, stones with HU values above 100, and cholelithiasis of a uniform calcification type were found to be symptomatic $(\mathrm{p}<0.05)$. However, the relationship between symptomatic cholelithiasis and stone size was not statistically significant ( $p>0.05)$. A comparison of the radiological features between symptomatic and asymptomatic cholelithiasis is shown in Table 3. In our study, no significant difference was noted in the sizes and numbers of stones obtained with CT and USG measurements $(\mathrm{p}>0.05)$. 
Our patients with cholelithiasis showed no symptoms other than cholecystitis, cholangitis, choledocholithiasis, and pancreatitis. A total of 26 (14.9\%) of our patients with cholelithiasis underwent cholecystectomy during their follow-up periods.

\section{DISCUSSION}

In general, $20-30 \%$ of cholelithiasis cases eventually show symptoms and complications, such as acute cholecystitis, chronic cholecystitis, choledocholithiasis, cholangitis, and acute pancreatitis (5). Patients with asymptomatic cholelithiasis can continue their lives without any clinical findings for years (5), and many cases are diagnosed incidentally with USG (6). In our study, 80 (45.9\%) of the 174 patients were radiologically symptomatic. This rate is higher than previously reported in the literature because of the higher number of radiographs and CT examinations conducted in symptomatic patients.

Cholelithiasis occurs two times more frequently in women than in men (2-4). In our study, $58 \%$ of the patients with cholelithiasis and $58.8 \%$ of the patients with symptomatic cholelithiasis were women. No significant difference was detected between the sexes for symptomatic cholelithiasis ( $>00.05$ ).

The size and the components of the stone affect the radiological features, and $15-20 \%$ of the cholelithiasis cases are radio-opaque $(2,7)$. The high level of calcium in the stone increases the likelihood of it being detected by radiography examination $(2,7,14,15,20)$. In our study,
$38.5 \%$ of the cholelithiasis stones were radio-opaque and $61.5 \%$ were radiolucent. Significant increases in symptomatic rates of radio-opaque cholelithiasis were found $(p<0.05)$. The reason for the high rate of radioopaque cholelithiasis in our study could be that radioopaque stones are symptomatic and are detected more frequently due to recent developments in radiographic techniques. An abdominal digital X-ray revealed millimeter-scale opaque stones (21).

Detection of cholelithiasis by CT is less likely when stones have a high cholesterol ratio and a low calcium ratio $(2,7,14,15,20)$. Pure cholesterol stones are isodense with bile (2). So they are usually invisible on CT. However, if pure cholesterol stones are large in size or contain some calcification, they can be visualized by CT. Cholelithiasis visualization by CT can be as high as $80 \%$ (14); in our study, $64.9 \%$ of the stones could be visualized by CT. Significant increases were observed in the symptomatic rates in patients with stones that could be visualized by CT. Significant increases were found in the symptomatic rates of patients with cholelithiasis visible in CT scans $(\mathrm{p}<0.05)$.

In our study, CT could not visualize the stones in 19 patients who had calcified stones less than $5 \mathrm{~mm}$ in size. The reason for this is that small stones may not be visualized on abdominal radiography due to their size, even if they are entirely calcified. Stones with $\mathrm{HU}$ values below 100 may be visible in CT scans, but may not be visualized by radiography. In our study, cholelithiasis could not be visualized in radiographs of 38 of the 46 patients with cholelithiasis with $\mathrm{HU}$ values below 100 . The stones with a $\mathrm{HU}$ of less than 100 were also less symptomatic (Table 3).

\begin{tabular}{|c|c|c|c|c|c|}
\hline Cholelithiasis features & Subtypes & Asymptomatic N (\%) & Symptomatic N (\%) & Totally & $\mathbf{P}$ \\
\hline \multirow{3}{*}{ Radiography } & Radiolucent & $73(77.7)$ & $34(42.5)$ & $107(61.5)$ & \multirow{3}{*}{$<0.001$} \\
\hline & Radio-opaque & $21(31.3)$ & $46(57.5)$ & $67(38.5)$ & \\
\hline & Totally & $94(100)$ & $80(100)$ & $174(100)$ & \\
\hline \multirow{3}{*}{ CT } & Invisible & $45(47.9)$ & $16(20)$ & $61(35.1)$ & \multirow{3}{*}{$<0.001$} \\
\hline & Visible & $49(52.1)$ & $64(80)$ & $113(64.9)$ & \\
\hline & Totally & $94(100)$ & $80(100)$ & $174(100)$ & \\
\hline \multirow{6}{*}{ Size } & $<5 \mathrm{~mm}$ & $21(22.3)$ & $21(26.2)$ & $42(24.1)$ & \multirow{6}{*}{0.559} \\
\hline & 5-15 mm & $37(39.4)$ & $31(38.8)$ & $68(39.1)$ & \\
\hline & $15-20 \mathrm{~mm}$ & $25(26.6)$ & $18(22.5)$ & $43(24.7)$ & \\
\hline & $20-25 \mathrm{~mm}$ & $9(9.6)$ & $5(6.25)$ & $14(8)$ & \\
\hline & $>25 \mathrm{~mm}$ & $2(2.1)$ & $5(6.25)$ & $7(4)$ & \\
\hline & Totally & $94(100)$ & $80(100)$ & $174(100)$ & \\
\hline \multirow{4}{*}{ Number } & Single & $53(56.4)$ & $21(26.25)$ & $74(42.5)$ & \multirow{4}{*}{$<0.001$} \\
\hline & A few pieces (2-4 pieces) & $27(28.7)$ & $41(51.25)$ & $68(39.1)$ & \\
\hline & Multipl ( $\geq 5$ pieces) & $14(14.9)$ & $18(22.5)$ & $32(18.4)$ & \\
\hline & Totally & $94(100)$ & $80(100)$ & $174(100)$ & \\
\hline \multirow{4}{*}{ HU values } & $<50$ & $18(36.7)$ & $10(15.4)$ & $28(16.1)$ & \multirow{4}{*}{$<0.001$} \\
\hline & $50-100$ & $12(24.5)$ & $6(9.2)$ & $18(10.3)$ & \\
\hline & $>100$ & $19(38.8)$ & $49(75.4)$ & $68(39.1)$ & \\
\hline & Totally & 49 (100) & $65(100)$ & $114(65.5)$ & \\
\hline \multirow{5}{*}{ Calcification type } & Uniform & $20(46.5)$ & $43(71.7)$ & $63(36.2)$ & \multirow{5}{*}{0.035} \\
\hline & Laminar & $4(9.3)$ & $6(10)$ & $10(5.7)$ & \\
\hline & Annular & $16(37.2)$ & $10(16.7)$ & $26(14.9)$ & \\
\hline & Central Nidus & $3(7)$ & $1(1.6)$ & $4(2.3)$ & \\
\hline & Totally & $43(100)$ & $60(100)$ & $103(59.1)$ & \\
\hline
\end{tabular}


The stones observed by CT were grouped into four calcification types: uniform, laminar, annular, and central nidus. The uniform type was the most frequently seen, while the central nidus type was the least frequently seen. The symptomatic rates were highest for the uniform calcification type (Table 3).

Stones larger than $2.5 \mathrm{~cm}$ carry a high risk of becoming symptomatic and causing complications $(4-6,16,22)$. In our study, no significant relationship was noted between symptoms and the size of the stone $(\mathrm{p}=0.559)$. Patients with more than one cholelithiasis had a high symptomatic rate (Table 3 ).

Cholecystectomy is the first choice treatment for symptomatic cholelithiasis (6). In our study, cholecystectomy was performed on 26 of 80 patients who were symptomatic during their follow-up periods. Oral dissolution therapy (ursodeoxycholic acid) or extra-corporeal shock wave lithotripsy (ESWL) is recommended for non-surgical patients (6), whereas bile acid dissolution therapy is recommended for floating stones $(<15 \mathrm{~mm}$ in diameter), for radiolucent or $<60$ HU stones detected by CT scans, and in patients with normal gallbladder function (6). In our study, 12 patients met these criteria. Of these, 5 patients with underwent ursodeoxycholic acid treatment, 3 patients underwent cholecystectomy, and 4 patients were followed up without any treatment.

ESWL therapy is recommended for single stones $(<20 \mathrm{~mm}$ in diameter $)$, radiolucent pure cholesterol stones ( $<50 \mathrm{HU}$ on CT scan, typical USG image), and in patients with normal gallbladder function (6). In our study, 38 patients met these criteria; however, only 4 patients were treated with ESWL. We think that the low rates of ursodeoxycholic acid and ESWL treatment in our study reflected the neglect of the radiological features of cholelithiasis in the treatment plan.

Current recommendations are that cholelithiasis should be monitored until symptoms develop $(4,5)$. However, the risk of developing symptoms or complications has increased in some patients, and these patients can undergo a prophylactic cholecystectomy. Considerations include the pediatric age group, sickle cell anemia, nonfunctioning gallbladder, porcelain gallbladder, and genetic susceptibility to gallbladder cancer, as well as the radiological features of cholelithiasis $(2,5,6,13)$.

The present study had some limitations, including the small sample size, the short duration of follow-up, and a lack of knowledge about the patients before and after the treatment. The assessment of the symptomatic cholelithiasis patients also did not include an evaluation between clinical and laboratory findings. Another limitation was that interobserver variability could not be determined because the examinations were performed by a single radiologist. Furthermore, the data and images are retrospective records. Nevertheless, the results of our study are meaningful, but additional comprehensive prospective studies are required that will involve detailed clinical findings with long follow-up periods.

\section{CONCLUSION}

No recent studies have reported the radiological features of cholelithiasis revealed by the technological advances in imaging devices. Our study shows the radiological features of cholelithiasis and its relationship with clinical symptoms. It can be considered determining factors in the treatment algorithm of cholelithiasis and are therefore important in terms of follow-up, treatment plan, and prevention of complications.

\section{ETHICAL DECLARATIONS}

Ethics Committee Approval: The study was carried out with the permission of Ethics Committee of Kirrkkale University Faculty of Medicine (Date: 24.10.2018, Number: 18/8).

Informed Consent: Because the study was designed retrospectively, no written informed consent form was obtained from patients.

Referee Evaluation Process: Externally peer-reviewed.

Conflict of Interest Statement: The authors have no conflicts of interest to declare.

Financial Disclosure: The authors declared that this study has received no financial support.

Author Contributions: All of the authors declare that they have all participated in the design, execution, and analysis of the paper, and that they have approved the final version.

\section{REFERENCES}

1. Catalano OA, Sahani DV, Kalva SP, et al. MR imaging of the gallbladder: a pictorial essay. Radiographics 2008; 28: 135-55.

2. Federle MP and Raman SP. Diagnostic Imaging: Gastrointestinal E-Book. Elsevier Health Sciences 2015.

3. Rumack CM, Wilson S, Charboneau JW, Levine D. Diagnostic Ultrasound: 2-Volume Set. Missouri: Elsevier Mosby 2010.

4. EASL Clinical Practice Guidelines on the prevention, diagnosis and treatment of gallstones. J Hepatol 2016; 65: 146-81.

5. Bellows CF, BErGEr DH and Crass RA. Management of gallstones. Am Fam Physician 2005; 72: 637-42.

6. Tazuma S, Unno M, Igarashi Y, et al. Evidence-based clinical practice guidelines for cholelithiasis 2016. J Gastroenterol 2017; 52: $276-300$

7. Tsai HM, Lin XZ, Chen CY, Lin PW, Lin JC. MRI of gallstones with different compositions. AJR Am J Roentgenol 2004; 182: 1513-9. 
8. Njeze GE. Gallstones. Niger J Surg 2013; 19: 49-55.

9. Trotman BW. Pigment gallstone disease. Gastroenterol Clin North Am 1991; 20: 111-26.

10. Trotman BW, Petrella EJ, Soloway RD, Sanchez HM, Morris TA 3rd, Miller WT. Evaluation of radiographic lucency or opaqueness of gallstones as a means of identifying cholesterol or pigment stones. Correlation of lucency or opaqueness with calcium and mineral. Gastroenterology 1975; 68: 1563-6.

11. Chan WC, Joe BN, Coakley FV, et al. Gallstone detection at CT in vitro: effect of peak voltage setting. Radiology 2006; 241: 546-53.

12. Stewart L, Griffiss JM and Way LW. Spectrum of gallstone disease in the veterans population. Am J Surg 2005; 190: 746-51.

13. Venneman NG and van Erpecum KJ. Pathogenesis of gallstones. Gastroenterol Clin 2010; 39: 171-83.

14.Brink JA, Kammer B, Mueller PR, Balfe DM, Prien EL, Ferrucci JT. Prediction of gallstone composition: synthesis of CT and radiographic features in vitro. Radiology 1994; 190: 69-75.

15. Dolgin SM, Schwartz JS, Kressel HY, et al. Identification of patients with cholesterol or pigment gallstones by discriminant analysis of radiographic features. New Eng Jo Med 1981; 304: 808-11.

16. Plaisier PW, Brakel K, van der Hul RL, Bruining HA. Radiographic features of oral cholecystograms of 448 symptomatic gallstone patients: implications for nonsurgical therapy. Eur J Radiol 1994 18: 57-60.

17. Ros E, Valderrama R, Bru C, Bianchi L, Teres J. Symptomatic versus silent gallstones. Radiographic features and eligibility for nonsurgical treatment. Dig Dis Sci 1994; 39: 1697-703.

18.Demehri FR and Alam HB. Evidence-Based Management of Common Gallstone-Related Emergencies. J Intensive Care Med 2016; 31: 3-13.

19. Raptopoulos V, Compton CC, Doherty P, et al. Chronic acalculous gallbladder disease: multiimaging evaluation with clinicalpathologic correlation. Am J Roentgenol 1986; 147: 721-4.

20. Fidler J, Paulson EK and Layfield L. CT evaluation of acute cholecystitis: findings and usefulness in diagnosis. Am J Roentgenol 1996; 166: 1085-8.

21. O'Kane D, Papa N, Manning T, et al. Contemporary Accuracy of Digital Abdominal X-Ray for Follow-Up of Pure Calcium Urolithiasis: Is There Still a Role? J Endourol 2016; 30: 844-9.

22. Ozbalci G, Tanrikulu Y, Kismet K, Dinc S, Akkus M. Gallstone ileus with a giant stone and associated multiple stones. Bratisl Lek Listy 2012; 113: 503-5. 